\title{
Predicted occurrence of ancient coppice woodlands in the Czech Republic
}

\author{
Petr Maděra, \\ Martin Machala, \\ Tomáš Slach, \\ Michal Friedl, \\ Linda Černušáková, \\ Daniel Volařík, \\ Antonín Buček
}

\begin{abstract}
Coppicing started in the Neolithic period and has been practiced throughout European history. This traditional silvicultural system was abandoned in many European countries during the $20^{\text {th }}$ century. The Czech Republic now has a very low proportion of coppice woods (CW), as more than $1000 \mathrm{~km}^{2} \mathrm{CW}$ were converted into high forests after World War II. Nevertheless, many CW were maintained as stored coppices, which could be the last remainders of ancient coppice woods (ACW) in the Czech Republic. Knowledge of area and distribution of stored coppices is currently missing in the Czech Republic, because they are recorded as high forests in forest management plans. Many stored forests are currently approaching the maturity age, with a high risk that these last ACW remainders will be lost; therefore, an inventory of ancient coppice woods is necessary. In our study, we develop an index of likelihood of coppice occurrence (COP) based on the distribution of habitats favourable for coppices, as well as on past and current occurrence of $\mathrm{CW}$ in the Czech Republic from historical maps. COP index values were then used to generate a map showing the relative likelihoods of occurrence of ACW, which can serve as a baseline to support the compilation of an ACW inventory and their mapping in the field. Our results can help prioritize forest areas to be inventoried based on their higher probabilities of ACW occurrence.
\end{abstract}

Keywords: Ancient Coppice Woodlands, Inventory, Coppice Occurrence, Cultural heritage
(Rackham 2003). Coppicing (Müllerová et al. 2014, Szabó et al. 2015) and pollarding (Mitchell 1989) were in widespread use as silvicultural systems until the beginning of the $20^{\text {th }}$ century, as shown by their frequent depiction in visual arts from this period (Lacina 2016). The first evidence of coppicing from the territory of the Czech Republic dates back to the year 1384 (Müllerová et al. 2014). However, coppices had been in use much earlier, with dendroarchaeological research revealing that coppicing started in the Neolithic and has been practiced throughout the European history (Szabó 2009). Brown \& Oosterhuis (1981) used the term "ancient coppice woods" to describe woodlands that had been continuously coppiced since at least the year 1800 AD. Similarly, the appearance of coppices with standards (Van Calster et al. 2008)
Much of the existing coppice woodland

are characterized as ancient woodlands woodlands in Greece, Italy, France, Bulgaria, Hungary, Spain, Portugal, Luxembourg, Belgium and Slovenia (Kadavy et al. 2011).

Department of Forest Botany, Dendrology and Geobiocoenology, Faculty of Forestry and Wood Technology, Mendel University in Brno, Zemedelská 3, 61300 Brno (Czech Republic)

@ (petrmad@mendelu.cz)

Received: Nov 25, 2016 - Accepted: Jun 16, 2017

Citation: Maděra $P$, Machala $M$, Slach T, Friedl $M$, Černušáková L, Volařík D, Buček A (2017). Predicted occurrence of ancient coppice woodlands in the Czech Republic. iForest 10: 788795. - doi: 10.3832/ifor2295-010 [online 2017-09-16]

Communicated by: Tomáš Vrška was documented as first occurring in Germany in $600 \mathrm{AD}$ and in France in the Middle Ages, and there are records from the $12^{\text {th }}$ century from England (Morhart et al. 2014). In Eastern European countries, the system was also well known since the Middle Ages (Machar 2009).

In ancient woodlands, natural processes interact with human activities in complex and subtle ways for centuries or millennia (Peterken 1996). Glaves et al. (2009) listed a wide range of ancient woodland values, including biodiversity, rarity, history and irreplaceability. There are three broad types of feature to look for in ancient woodland according to Glaves et al. (2009): (i) vascular plant indicators; (ii) tree shape and form; and (iii) surface and buried archaeology.

Many ancient woods hold amazingly rich resources of archaeology and local history (Rotherham \& Ardron 2006) that are only little altered by modern cultivation or disturbance (Anonymous 2012). For example, Szabó (2010a) mentioned that in Western and Central Europe, many ancient woods are clearly separated from the surrounding countryside by permanent physical boundaries. While such boundaries (woodbanks, walls, stone rows and lynchets) are now out of use, they were widespread and important landscape features in the past.

The main component of ancient coppice woodlands is the presence of ancient coppice stools, which can reach 1000 years in 
age and demonstrate the long-term continuity of coppicing (Rackham 1986, Pigott 1989, Vrška et al. 2017). In addition to the ancient coppice stools, the presence of tree microhabitats (Winter \& Möller 2008), especially water filled cavities (dendrotelms - Kitching 1971) are among the important natural features increasing biodiversity. The ancient coppice woodlands are often species-rich and host many globally threatened plant and animal species (Rackham 2006). Stand-scale survival of light-demanding species and their coexistence with shade-tolerant species is ensured by the shifting mosaic of different-aged patches created by coppicing (Decocq et al. 2004). Over-aged coppice stands provide important habitat conditions for saproxylic species and unique herbaceous layers (Mölder 2016). Coppicing and woodpasture have resulted in woodland habitats that are nowadays highly valued for nature conservation due to their rich biodiversity (Müllerová et al. 2015). Most forest habitats listed in the Habitats Directive of the European Union (Council Directive 92/43/ EEC) for their nature conservation importance result from centuries of human intervention. Mairota at al. (2016) proposed a list of 53 forest habitat types (68\% of the 78 Annex I forest habitat types) capable of being managed as coppices. The majority (55\%) fall into " 9100 Forests of Temperate Europe".

The demise of traditional forest management, in particular its most widespread form - coppicing, is considered to be a driver of forest biodiversity decrease (Hédl et al. 2010), resulting in changes in both plant communities (Hédl et al. 2010, Kopecky et al. 2013, Müllerová et al. 2015) and invertebrate populations (Benes et al. 2006). Indeed, the occurrence of red-list species diminishes considerably after coppice abandonment (Müllerová et al. 2015).

Coppicing was abandoned in many European countries during the $20^{\text {th }}$ century (Müllerová et al. 2014). Most coppice woods were converted into high forests. To stop the process of diminishing biodiversity and support the goals of nature conservation, Müllerová et al. (2015) proposed the re-establishment of coppice management. This is not possible without an inventory of existing ancient coppice woodlands (Spencer \& Kirby 1992).

In the Czech Republic, Kadavy et al. (2011) described only 7000 ha of coppice forests in 1990 ( $0.3 \%$ of the forest area); however, most of them are not ancient, for example Robinia pseudoacacia (Black locust) coppice woods. On the other hand, many coppice woods were converted into stored coppices (i.e., overaged coppices) and if there are any well-preserved coppice stools, we can regard them as ancient coppice woods and suppose the presence of other natural and historical elements. The conversion and abandonment of coppice woods culminated in the Czech Republic after World War II, meaning that many of their remain- ders and stored coppice are currently approaching maturity. There is a great risk that these last remainders of the ancient coppice woods will be lost.

No historical maps from before 1941 are available for the whole area of the Czech Republic to document coppice woodland distribution and continuity, and thus to prove the existence of ancient coppice woodlands. The present paper aims at creating a set of maps of historical, present and potential occurrences (based on favourable habitat) of coppice woodlands in order to infer the likely distribution of remaining ancient coppice woodlands in the Czech Republic. This distribution would help prioritise areas to be included in the field inventory and subsequent conservation of ancient coppices.

\section{Material and methods}

\section{Study area}

We focused on the whole area of the Czech Republic (centroid coordinates: $49.78^{\circ} \mathrm{N}, 15.67^{\circ} \mathrm{E}$ ), which covers 78,866 $\mathrm{km}^{2}$. Of this area, $34 \%$ is covered by forests. The altitude varies from 115 to $1603 \mathrm{~m}$ a.s.l., mean annual temperature from 2 to $10{ }^{\circ} \mathrm{C}$ and mean annual sum of precipitation from 450 to $1200 \mathrm{~mm}$. Within the geobiocoenological classification of forests (Buček et al. 2015), nine altitudinal vegetation zones are distinguished according to prevailing tree species. From lowlands to mountains, the prevailing species are: Quercus spp. (oak), Fagus sylvatica (European beech), Abies alba (silver fir) and Picea abies (Norway spruce). The territory of the Czech Republic is divided into more than 13,000 cadastral areas. The cadastral areas are grouped into 206 administrative districts known as "Municipalities with Extended Competence" (hereinafter MECs) within two geographically different regions: Bohemia (western part) and Moravia (eastern part of the (zech Republic).

\section{Input data}

We collected data for all the cadastral areas of the Czech Republic, although several data were not available at the cadastral area level and were collected directly at the MEC level. All input data were finally summarised and analysed at the MEC level. In addition, appropriate maps were created based on the MEC layer (Source: ARC CR 500).

For each MEC, we estimated both its total area of forest land and its absolute area of ACW by combining different data sources with the methodology described below. This enabled to compare MECs based on the proportions of their forested land occupied by ACW, thus eliminating the influence of MEC size. We also assigned the woodlands in each MEC to suitability classes for ACW establishment (based on natural conditions) and calculated, across MECs, the mean percentage MEC woodlands in each suitability class.

\section{Natural conditions}

We used altitudinal vegetation zones (AVZs) as the main information source on natural conditions influencing the occurrence of coppice woodlands for three main reasons. First, they carried information about the main tree species in forest species composition, which is a crucial prerequisite for coppicing, as tree species differ in sprouting ability (Bond \& Midgley 2001). Second, there is a long history of AVZ mapping in the Czech Republic, resulting in detailed information available on AVZs for the whole country (e.g., stored in the biogeography register, which is a database where information about AVZ distribution is stored at the cadastral areas level Vlčková et al. 2015). Third, the characterization of AVZs contains information about climatic conditions, which are the main driver influencing coppices distribution (Szabó et al. 2015). The gradient in tree species composition ranges from good resprouters at lower altitudes and low AVZs (e.g., oaks and hornbeam - Carpinus betulus) to a worse resprouter (beech) and finally to non-resprouters (the conifers silver fir and Norway spruce) at higher altitudes in mountains.

To obtain information about AVZs for the whole Czech Republic, we used the biogeography register (Vlčková et al. 2015). In particular, this register contains information about the representation of AVZs for each cadastral area, using 26 codes of which seven include only one AVZ and 19 are heterogeneous, combining more than one AVZ.

To evaluate natural conditions favourable for the establishment of coppice woodlands, we classified the AVZ codes into five categories (A-E) according to prevailing tree species and assigned them relative weights based on their relative suitability for coppice woodlands. Very favourable natural conditions for the establishment of coppice woodlands (category A) were expected in AVZs with oak as a prevailing species, i.e., in AVZ 1 ("Oak") and AVZ 2 ("Beech-Oak", mainly oak with an admixture of beech), and favourable natural conditions (category B) where oak has a considerable representation (AVZ 3, "OakBeech", mainly beech with an admixture of oak). In these two categories, natural forest biocoenoses enable coppice establishment not only because of the abundance of oak, which is a good resprouter, but also because they contain significant amounts of hornbeam, which resprouts even better than oak (Matula et al. 2012). The less-favourable (category C, AVZ 4) and unfavourable (category D, AVZ 5) both feature AVZs in which beech is dominant. Beech is a tree species with lower resprouting ability than oak (Ellenberg 1986), and the AVZs falling in this category are not accompanied by large representations of oak or hornbeam. Very unfavourable conditions (category E) comprise AVZs (AVZ 6 and higher) with a significant share or do- 
minance of the conifer species Norway spruce or silver fir.

For each MEC, we extracted the percentage of total area in each AVZ category, multiplied it by the weight of the category and summed those values to obtain one number for the MEC, which we called its NC (Natural Conditions) index. Weights were assigned based on the assumption that the probability of establishing coppice woodlands in unfavourable conditions would be ten times less likely than in very favourable conditions; this was based on our observations gathered while field mapping ACW in different altitudinal vegetation zones (manuscript in preparation). The weights are shown in the following equation used to calculate the NC index values (eqn. 1):

\section{$N C=0.1 \cdot A+0.07 \cdot B+0.04 \cdot C+0.01 \cdot D+0 \cdot E$}

where $A, B, C, D, E$ are percentage shares of areas of the individual categories of natural conditions in MECs. NC index values range from 0-10. The whole gradient of NC index values was finally divided into intervals used to characterize the potential for establishment of coppice woodlands in each MEC: (i) very unfavourable: 0.0-0.8; (ii) unfavourable: 0.9-2.6; (iii) less favourable: 2.7-5.3; (iv) favourable: 5.4-8.0; (v) very favourable: 8.1-10.0.

\section{Historical occurrence of coppice woodlands}

\section{Coppice woodlands area in $\mathbf{1 8 4 5}$}

To obtain information about occurrence of coppice woodlands in the mid-19 ${ }^{\text {th }}$ century, we used land use registry records from 1845 which are available for each cadastral area. These records are based on results of the mapping of stable cadastres (over the period 1826-1843) at the scale 1:2880 (Bičík et al. 2010). For forests, they list areas of high forests (divided into broadleaved, coniferous and mixed), coppice woods, glades, shrublands, landscape parks and burnt-over areas. Thus, they constitute a unique source of information about the condition of forest stands for this period. They are now publicly available on the web (http://archivnimapy.cuzk.cz), from which we manually gathered the information on the area of coppice woods for all of the over 13,000 cadastres and stored this information in our database.

\section{Area of coppice and oak woodlands in 1941 and 1947}

We next gathered information about coppice woodlands and oak woodlands distribution about 100 years later, as provided in two maps - one from 1941 (Svoboda \& Weingartel 1941), and one from 1947 (Svoboda 1947). On both maps, the main tree species composition (e.g., oak forest) and designation as coppice vs. high forest are indicated. We were interested both in areas designated as coppices and those indi- cated to be oak woodlands. The map from 1941 covers about $92 \%$ of the area of the Czech Republic, and that from 1947 encompasses its whole area. Both maps are available as just a few original copies and with rather uncertain purpose and methodology of their creation. The map from 1947 is probably derived from first one.

Both maps were digitized on a high-resolution large-format scanner and georeferenced, and then all polygons containing coppice and oak woodlands were manually vectorized. We used information about coppice and oak woodlands occurrence from the map from 1941, and then used the map from 1947 just for the area not covered by the map from 1941. The results were two maps, one with coppices in $1941 / 1947$ and one with oak woodlands in 1941/1947.

\section{Current occurrence of coppice \\ woodlands}

We used two sources for current occurrence of coppice woodlands: the Natura 2000 list of habitats and comprehensive forest management plans. Both sources were useful but limited. Indeed, Natura 2000 was not designed to collect information about forest management practices, neither present nor past (high forest/coppice). Forest management plans, on the other hand, often listed stored coppices as high forests because they were the preferable management practice from the mid$20^{\text {th }}$ century.

\section{Natura 2000 habitats}

Mapping of habitat types for Natura 2000 (Chytry et al. 2010) was carried out in the whole Czech Republic in 2001-2004 and has been continually updated since 2006 . As a result, Natura 2000 maps contain relatively accurate and up-to-date information about the habitat types included in the habitat type catalogue of the Czech Republic (Chytry et al. 2010), although coppices (or stored coppices) and high forest are not distinguished in these maps. Nevertheless, we were able to deduce the likelihood of each habitat type consisting of coppices (including stored coppices). First, we chose all habitat types for which coppice occurrence is possible by the representation of tree species able to resprout mentioned in the habitat types description (22 such habitat types in total). Although some of these habitat types often consist of (primarily stored) coppices (e.g., oak-hornbeam forests), some of them contain actual or stored coppices in only very few cases (e.g., limestone beech forest). Therefore, in the second step we estimated the probability each of these habitats to include (actual or stored) coppices (Tab. 1). These probabilities were determined by repeated assessment by experts with long-term experience in habitat mapping, and they were multiplied by the area of each particular habitat type in MEC, weighting them accordingly.
Tab. 1 - Types of habitats listed in Natura 2000 (Chytry et al. 2010) with estimated probabilities (\%) of occurrence of coppice woods (Prob.).

\begin{tabular}{llc}
\hline Code & Habitat type & $\begin{array}{c}\text { Prob. } \\
\text { (\%) }\end{array}$ \\
\hline K3 & Tall mesic and xeric scrub & 5 \\
\hline L1 & Alder carrs & 10 \\
\hline L2.2 & Ash-alder alluvial forests & 15 \\
\hline L2.3 & Hardwood forests of & 10 \\
& lowland rivers & \\
\hline
\end{tabular}

L2.4 Willow-poplar forests of lowland river

L3.1 Hercynian oak-hornbeam forests

L3.2 Polonian oak-hornbeam forests

L3.3 Carpathian oak-hornbeam forests

L3.4 Pannonian oak-hornbeam forests

L4 Ravine forests

L5.1 Herb-rich beech forests

L5.3 Limestone beech forests

50

60

50

75

L5.4 Acidophilous beech forests

L6.1 Peri-alpidic thermophilous oak forests

L6.2 Pannonian thermophilous 70 oak forests on loess

L6.3 Pannonian thermophilous 50 oak forests on sand

L6.4 Central European basiphilous thermophilous oak forests

L6.5 Acidophilous thermophilous oak forests

L7.1 Dry acidophilous oak forests

L7.2 Wet acidophilous oak forests

L7.3 Subcontinental pine-oak forests

L7.4 Acidophilous oak forests on sand

90 50

For each MEC, the current areas of selected Natura 2000 habitat types were obtained from the Nature and Landscape Conservation Agency of the Czech Republic, multiplied by their weighting factors (from Tab. 1) and summed to obtain the estimated current occurrence of coppice woods within it.

\section{Comprehensive forest management plans}

We next obtained information on locations and areas of forests listed as coppice woods and coppices with standards from the database of comprehensive forest management plans administered by the Forest Management Institute in Brandýs nad Labem. We used these data to calculate the area of coppices and coppices with standards in each MEC. Although comprehensive forest management plans contained directly information about coppicing, they lacked many stored coppices (Kadavy et al. 2011). 
Tab. 2 - Summary of criteria used to calculate COP index reflecting the potential for AWC occurrence in MECs. (Range): range of values in MECs; (Total points): total points in all MECs.

\begin{tabular}{|c|c|c|c|c|c|}
\hline Criteria & Label & Source & Value & Range & $\begin{array}{l}\text { Total } \\
\text { points }\end{array}$ \\
\hline $\begin{array}{l}\text { Natural conditions for coppice woodland } \\
\text { establishment }\end{array}$ & NC index & $\begin{array}{l}\text { Biogeography register } \\
\text { (Vlčková et al. 2015) }\end{array}$ & NC Index & $0-10$ & 717.1 \\
\hline Area of coppice woods in 1845 & C_area ${ }_{1845}$ & $\begin{array}{l}\text { Land use registry records } \\
\text { from stable cadastre }\end{array}$ & Area $\left(\mathrm{km}^{2}\right)$ & $0-76.87$ & 1457.27 \\
\hline Area of coppice woods in $1941 / 1947$ & C_area ${ }_{1941}$ & $\begin{array}{l}\text { Maps from } 1941 \text { and } 1947 \text { (Svoboda \& } \\
\text { Weingartel 1941, Svoboda 1947) }\end{array}$ & Area $\left(\mathrm{km}^{2}\right)$ & $0-59.29$ & 1031.79 \\
\hline Area of oak woods in $1941 / 1947$ & Oak_area 1941 & $\begin{array}{l}\text { Maps from } 1941 \text { and } 1947 \text { (Svoboda \& } \\
\text { Weingartel 1941, Svoboda 1947) }\end{array}$ & Area $\left(\mathrm{km}^{2}\right)$ & $0-25.7$ & 226.72 \\
\hline $\begin{array}{l}\text { Current area of coppice woods and coppice } \\
\text { with standards according to forestry records }\end{array}$ & C_forestry & $\begin{array}{l}\text { Comprehensive forest management } \\
\text { plans }\end{array}$ & Area $\left(\mathrm{km}^{2}\right)$ & $0-16.86$ & 109.88 \\
\hline $\begin{array}{l}\text { Area of Natura } 2000 \text { biotopes with inferred } \\
\text { occurrence of coppice woodlands }\end{array}$ & C_Natura & $\begin{array}{l}\text { Natura } 2000 \text { habitats distribution } \\
\text { database }\end{array}$ & Area $\left(\mathrm{km}^{2}\right)$ & $0.21-56.18$ & 1390.68 \\
\hline
\end{tabular}

\section{Data synthesis} 2):

We synthesized all the above-mentioned input data (overviewed in Tab. 2), constructing an index that we called the COP index. The COP index was calculated for each MEC simply by summing the value of the NC index, the areas of coppice woods from each period/source and half the area of oak woods in 1941/1947, as follows (eqn.

$$
\begin{aligned}
C O P & =N C+C \_ \text {area }_{1845}+C \_ \text {area }_{1941} \\
& +(\text { Oak_area } 1941 / 2)+C \_N a t u r a \\
& +C \text { forestry }
\end{aligned}
$$

(for abbreviations see Tab. 2). The area of oak woods (and thus its weight in the calculation) was divided by two in the index formula to reflect the uncertainty regarding to what extent the oak forests in 1941/ 1947 were in fact coppices.

Finally, the range of COP values was divided into classes reflecting the inferred likelihood of occurrence of ancient coppice woodlands (ACW) in a given MEC. These likelihoods were inferred based upon several MECs where we mapped the actual distribution of ACWs in the field (data not

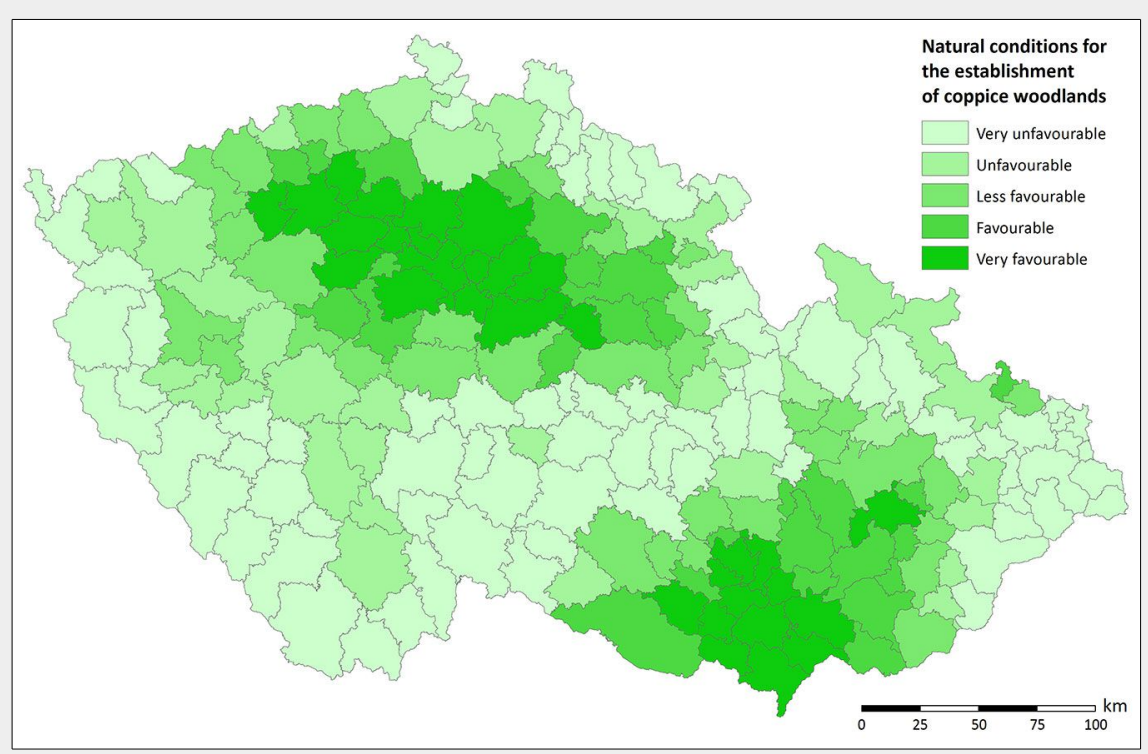

Fig. 1 - Map of natural conditions for the potential establishment of coppice woodlands in the Czech Republic.

Tab. 3 - Number of MECs, areas of MECs and forest areas in MECs by individual NC index classes, i.e., according to natural condition for establishment of coppice woodlands (in \%).

\begin{tabular}{lcccc}
\hline $\begin{array}{l}\text { Natural conditions for } \\
\text { coppice establishment }\end{array}$ & $\begin{array}{c}\text { NC } \\
\text { Index }\end{array}$ & $\begin{array}{c}\text { MECs } \\
\text { Number (\%) }\end{array}$ & $\begin{array}{c}\text { MECs } \\
\text { Area (\%) }\end{array}$ & $\begin{array}{c}\text { Forest area } \\
\text { in MECs (\%) }\end{array}$ \\
\hline Very unfavourable & $0.00-0.83$ & 24.7 & 27.1 & 44.8 \\
Unfavourable & $0.84-2.59$ & 30.6 & 31.1 & 35.0 \\
Less favourable & $2.60-5.30$ & 15.0 & 14.4 & 33.2 \\
Favourable & $5.31-8.06$ & 15.5 & 15.1 & 25.0 \\
Very favourable & $8.07-10.00$ & 14.1 & 12.3 & 18.0 \\
\hline
\end{tabular}

shown). The classes of predicted occurrence of ACW were as follows: (i) very low: COP index values 0.43-10.00; (ii) low: 10.0125.00; (iii) moderate: $25.01-50.00$; (iv) high: 50.01-100.00; (v) very high: 100.01-175.00.

\section{Results}

Natural conditions for the establishment of coppice woodlands

The best natural conditions for the establishment of coppice woodlands (Fig. 1) are in MECs with NC index values reaching the maximum (10.00) because they are located entirely in the altitudinal vegetation zones 1 (Oak) and 2 (Beech-Oak). These include three MECs in Bohemia, and six MECs in Moravia.

More than a quarter of the Czech territory $(27.4 \%)$ exhibits very favourable or favourable natural conditions for the establishment of coppice woodlands. However, these areas also feature a very low percentage of forest land, considerably below the national average. Specifically, the regions with very favourable or favourable conditions for the establishment of coppice woodlands show percentages of forest land only $18.0 \%$ and $25.0 \%$, respectively, and their total present-day forest area amounts to $4733.4 \mathrm{~km}^{2}(17.7 \%$ of the area of Czech forests - Tab. 3).

\section{Area of coppice woods in 1845}

The total detected area of coppice woods in 1845 amounted to $1457.4 \mathrm{~km}^{2}$. It is rather surprising that only two MECs did not show any occurrence of coppice woods in that period. More than 1000 ha of coppice woods occurred in 44 MECs (over $25 \%$ ). Thus, the coppice woods were recorded at least as small parcels across nearly the whole territory of the Czech Republic (Fig. 2).

\section{Area of coppice and oak woods in 1941 and 1947}

The total area of coppice woods in 1941 and 1947 (Fig. 3) amounted to $1031.791 \mathrm{~km}^{2}$. In this period, $111 \mathrm{MECs}$ (i.e., more than 50 $\%)$ already reported no areas of coppice woods, and only $10 \%$ of MECs had areas of 
coppice over 1000 ha.

The area of oak woodlands reached 453.4 $\mathrm{km}^{2}$ in this period (Fig. 3). Although the oak woods are not specified as coppice woods in the maps from 1941 and 1947, many of them were probably of coppice origin, and some still likely managed by coppicing.

Estimated occurrence of coppice woods based on Natura 2000 habitats

We estimate the current occurrence of coppice woods (Fig. 4) based on Natura 2000 habitats to total $1390.7 \mathrm{~km}^{2}$ in the territory of the Czech Republic. All MECs feature at least a small area of habitat types that could harbour coppice woods. More than 1000 ha of such habitat occurs in each of $46 \mathrm{MECs}$ (i.e., more than $25 \%$ of all MECs). The values are very close to those indicating the historical occurrence of coppice woods.

\section{Current area of coppice woods and} coppices with standards according to comprehensive forest management plans

Data from forest management plans indicate the area of coppice woods and coppice with standards (i.e., the forest area in which the coppice system of management is actively used - Fig. 4) is $109.9 \mathrm{~km}^{2}$ (92.28

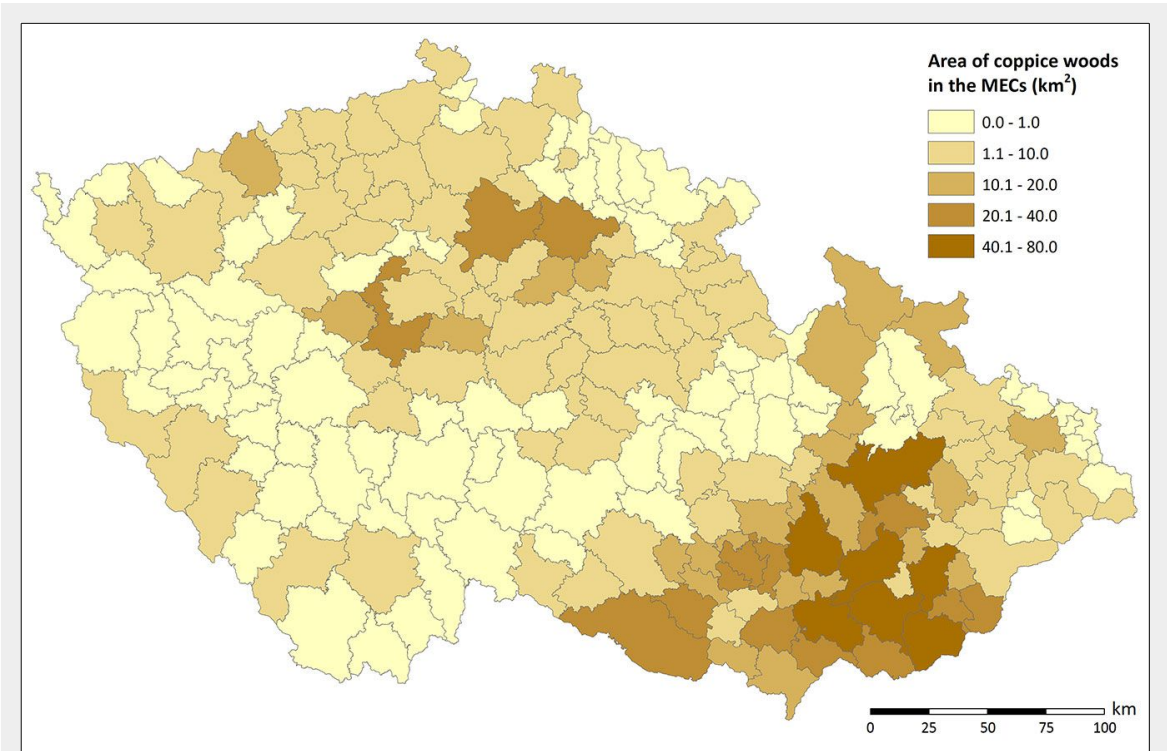

Fig. 2 - Map of the area of coppice woods in the Czech Republic in 1845.

$\mathrm{km}^{2}$ and $17.60 \mathrm{~km}^{2}$, respectively). Forests of these two types are missing in 137 MECs (more than $60 \%$ ). In the majority of the MECs in which they do occur, they occupy areas smaller than $1 \mathrm{~km}^{2}$, and only $18 \mathrm{MECs}$ (less than $10 \%$ ) currently feature areas of coppice woods and coppice with standards larger than $1 \mathrm{~km}^{2}$. Most coppice woods and coppices with standards recorded in the Forest Management Institute database are concentrated in traditional coppicing regions, i.e., the hilly areas of central Bohemia and the lowlands and hilly areas of southern Moravia.

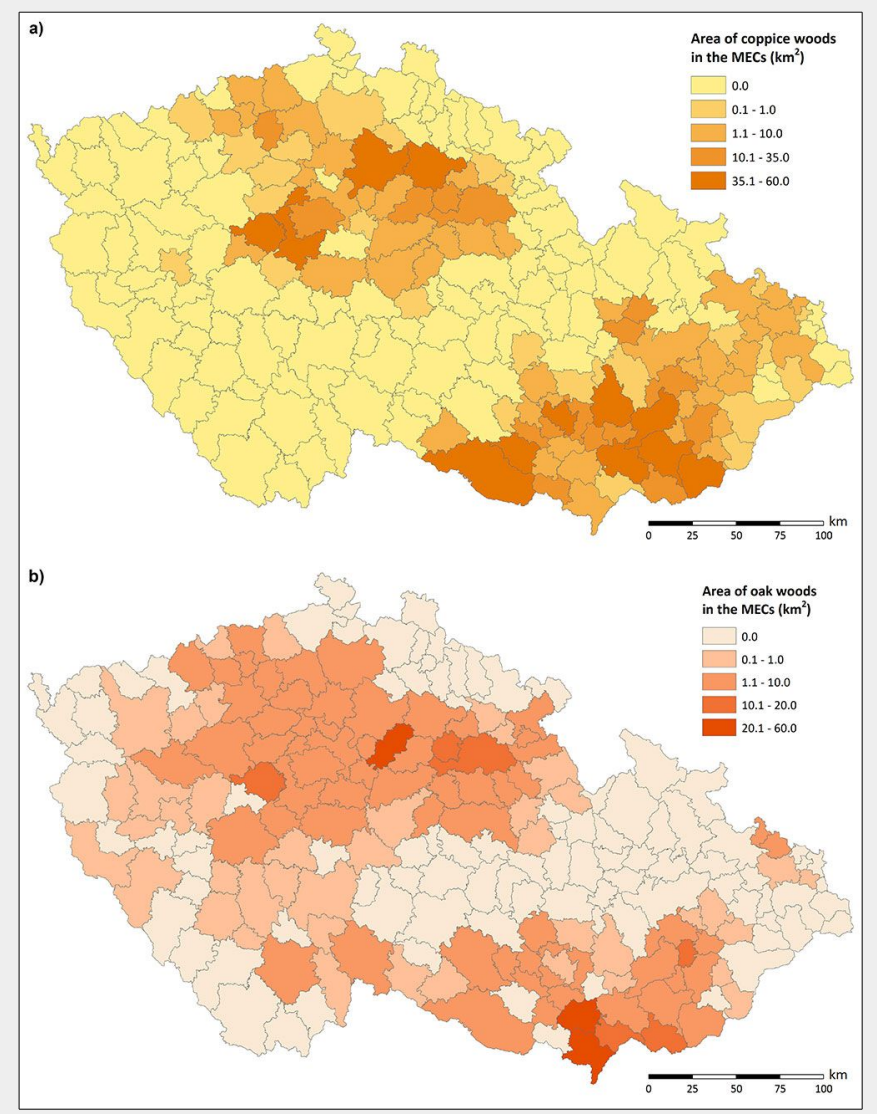

Fig. 3 - Map of coppice woods in 1947 (a) and map of oak woods in 1947 (b) in the Czech Republic.

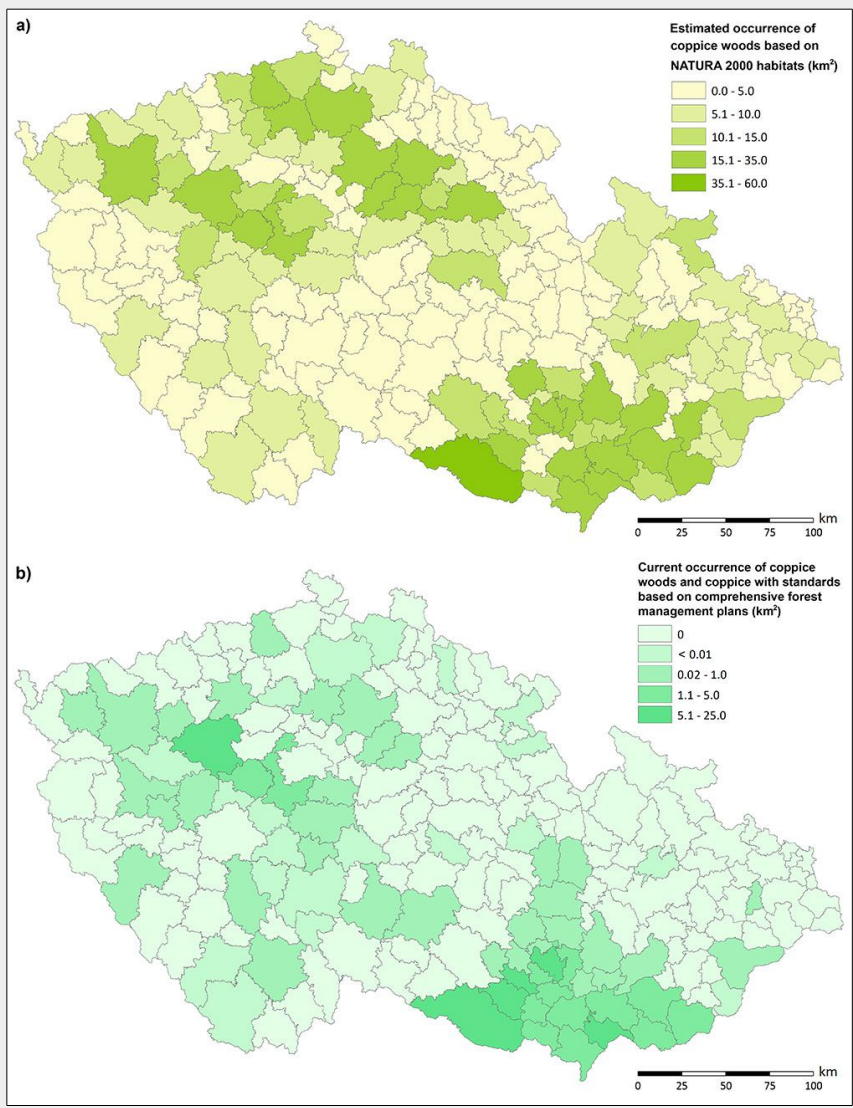

Fig. 4 - Map of estimated occurrence of coppice woods based on NATURA 2000 habitats (a) and map of current occurrence of coppice woods and coppice with standards based on comprehensive forest management plans (b). 


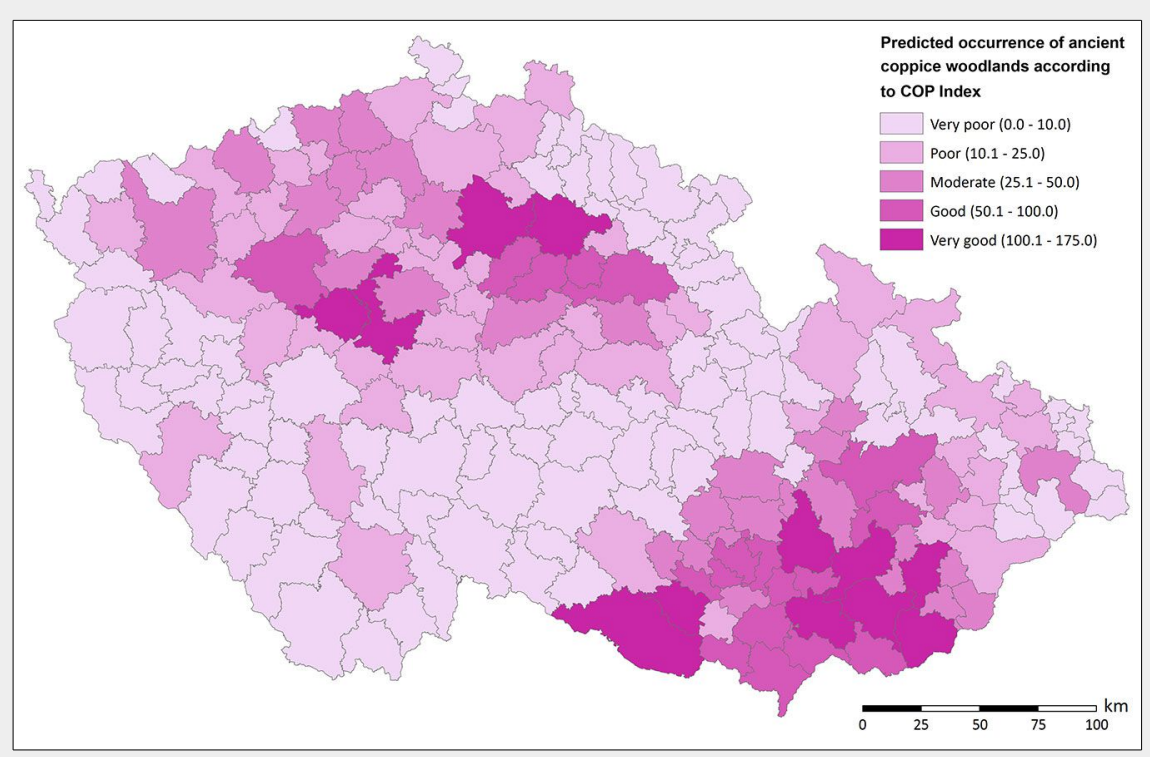

Fig. 5 - Map of predicted occurrence of ancient coppice woodlands in the Czech Republic, according to the COP Index.

Tab. 4 - Number of MECs, area of MECs and forest area in MECs by individual COP index classes, i.e. according to predicted occurrence of ancient coppice woodlands (in $\%)$.

\begin{tabular}{lcccc}
\hline $\begin{array}{l}\text { Predicted ACW } \\
\text { occurrence }\end{array}$ & $\begin{array}{c}\text { COP Index } \\
\text { class }\end{array}$ & $\begin{array}{c}\text { MECs Number } \\
\text { (\%) }\end{array}$ & $\begin{array}{c}\text { MECs Area } \\
\text { (\%) }\end{array}$ & $\begin{array}{c}\text { Forest area } \\
\text { in MECs (\%) }\end{array}$ \\
\hline Very low & $0-10.0$ & 48.1 & 44.3 & 49.6 \\
Low & $10.1-25.0$ & 24.3 & 26.2 & 26.6 \\
Moderate & $25.1-50.0$ & 13.6 & 12.6 & 10.7 \\
High & $50.1-100.0$ & 8.3 & 8.2 & 5.9 \\
Very high & $100.1-175.0$ & 5.8 & 8.7 & 7.3 \\
\hline
\end{tabular}

\section{Predicted occurrence of ancient coppice} woodlands

The final map created according to the COP index shows the predicted occurrence of ancient coppice woodlands (Fig. 5); where higher COP index values in MECs indicate larger areas of ancient coppice woodlands. Very high COP values were found for 12 MECs (total area $6850.3 \mathrm{~km}^{2}$ ) with a total of $1939.4 \mathrm{~km}^{2}$ of forests. High COP values apply to 17 MECs (total area $6492.0 \mathrm{~km}^{2}$ ) with $1574.1 \mathrm{~km}^{2}$ of forests, and moderate COP values were obtained for 28 MECs (total area $9963.8 \mathrm{~km}^{2}$ ) with 2840.9 $\mathrm{km}^{2}$ of forests. On the other hand, very low COP values were found for 99 MECs (total area $34911.8 \mathrm{~km}^{2}$ ) with $13,216.0 \mathrm{~km}^{2}$ of forests, and low COP values were found for 50 MECs (total area: $20,648.8 \mathrm{~km}^{2}$ ) with $7093.4 \mathrm{~km}^{2}$ of forests. These values are expressed as percentages in Tab. 4.

\section{Discussion}

Coppicing and pollarding were the most widespread historical silvicultural systems in broadleaved forests of the European part of the deciduous temperate forest zone from Neolithic times until the early $20^{\text {th }}$ century (Mitchell 1989 , Stajic et al. 2009, Szabó 2009, Müllerová et al. 2014, Szabó et al. 2015), when they were abandoned in many European countries (Szabó 2010b, Szabó \& Hédl 2013, Müllerová et al. 2015). The decrease in coppicing is well documented by our source data, as coppice woodlands occurred on an area of $1457.4 \mathrm{~km}^{2}$ in 1845 and only $109.9 \mathrm{~km}^{2}$ in 2013. In most Central and North-Western European countries (where coppice woodlands were dramatically transformed into high forests), coppice woodlands and especially stored coppices and coppices with standards are now considered from a biodiversity conservation perspective as valuable forest habitat, providing important conditions for saproxylic species and a unique herbaceous layer (Mölder 2016). However, scientifically-trained foresters in the $19^{\text {th }}$ and $20^{\text {th }}$ century apparently associated traditional management forms (including coppicing) with degradation and depletion, and also with poor timber quality (Vandekerkhove et al. 2016).

Nowadays, a similar preference for noncoppice woodlands is fairly common in those European countries that still have high proportions of coppice forests. For example, in the Umbria region (Central Italy) a number of conservation plans recommend the conversion to high forest for Natura 2000 specific forest habitat types (Mairota et al. 2016). Thus, it appears that the biodiversity benefits of coppices that are now recognized in countries which suf- fered from their loss are not yet appreciated in countries where coppices are still relatively abundant.

The situation in the Czech Republic is more complicated. Although the benefits of ACW are appreciated by conservationists, most foresters still consider coppices as poor quality and undesirable woodlands, and are thus not involved in efforts to re-establish coppicing. This outlook is likely due to the fact that $100 \%$ of forests were in state ownership until as recently as 1989. In contrast, coppice structures have persisted in the Osnabrück region (NW Germany) until today, which Mölder (2016) mainly attributed to the low economic importance of small private forest parcels, as well as the individualism of the forest owners.

Based on a careful study of archival sources, Szabó et al. (2015) argued that coppicing was not only widespread in the lowland regions of Moravia in the Late Middle Ages but also rather predominant or even exclusive. Practically every lowland wood was intensively managed by coppicing. Szabó et al. (2015) calculated the area of woodlands needed to obtain firewood to be $4500 \mathrm{~km}^{2}$ in Moravia in the Late Middle Ages ( $15 / 16^{\text {th }}$ century). Most of that area probably consisted of coppices. Our results show that in 1845 there were only 1457.4 $\mathrm{km}^{2}$ of coppice woodlands in the current territory of the Czech Republic, suggesting that the decrease in coppices started before 1845 . The area of coppice woodlands in 1845 estimated in this study is in good agreement with the historical data on the distribution of coppice woodlands in the Czech Republic; according to the revised cadastre from 1900 it was $1550 \mathrm{~km}^{2}$ (Kadavy et al. 2011) of which $950 \mathrm{~km}^{2}$ were coppice woodlands and $600 \mathrm{~km}^{2}$ coppices with standards. These data suggest that the conversion of coppice woodlands into high forests began before the $19^{\text {th }}$ century. Already in the $17^{\text {th }}$ century, the practice of selecting coppice stools for conversion to stored coppices was recorded in management instructions (Müllerová et al. 2014).

In countries where the conversion of most coppice woods into high forests has been completed, there is a danger of losing biodiversity (Bradshaw et al. 2015). For the Czech Republic, we estimated $1390.7 \mathrm{~km}^{2}$ of coppice woodlands (mostly stored coppices), found within 22 Natura 2000 habitat types (as listed by Chytry et al. 2010), i.e., $58 \%$ of the forest habitat types in the country. Mairota et al. (2016) found that there were 53 EUNIS Database habitat types with potential for coppice within the $28 \mathrm{EU}$ member countries, of which 11 types were found to potentially be coppiced in the Czech Republic. The characterization of EUNIS habitat types is generally broader than that of habitat types published for the Czech Republic by Chytry et al. (2010). This largely explains the greater number of Natura 2000 habitat types that we found to likely contain coppices. According to our 
estimation, on average, $38 \%$ of area of the 22 mentioned Natura 2000 habitat types (Tab. 2) could be covered by coppice (mostly stored coppice).

Similarly, the cultural and historical heritage relating to ancient coppice woodlands could be threatened (Rotherham \& Ardron 2006, Szabó 2010a). The failure to identify ancient coppice woodlands may result in accidental damage to the sites by management activities, which could otherwise be avoided (Rotherham \& Ardron 2006). Thus, especially in stored coppices, the small archaeological features such as boundary stones, boundary trees, old paths, woodbanks, walls, stone rows, lynchets (Szabó 2010a) could be destroyed by harvesting.

To conserve the natural and cultural heritages associated with ancient woodlands, the Nature Conservation Council of Great Britain created an ancient woodlands inventory in the 1980s. Ascertaining and maintaining the condition of ancient woodland in Great Britain will be a major challenge for the future (Goldberg et al. 2007). The inventory forms the basis for more detailed follow-up surveys and contributes to the development of woodland conservation policies. It provides a baseline against which the success of these policies can be monitored (Spencer \& Kirby 1992). In the Czech Republic, there is a similar need for an inventory of ancient coppice woodlands because their remainders will reach maturity soon, thus they will be harvested in the near future and replaced by high forests.

Our approach combines both historical and environmental data. Our predictions of the occurrence of ancient coppice woodlands is based on the evaluation of historical, current and potential coppice woodland distributions within MECs. We combined all these sources to generate information about possible occurrence of ancient coppice woodlands that was as accurate as possible. Each of these sources has some weakness when considered individually. Current records of coppice woodland occurrence are very sparse and many stored coppices have been likely reported as high forests by forest managers (Kadavy et al. 2011). Although historical records go back to the $14^{\text {th }}$ century (Müllerová et al. 2014) they are dispersed in archives and do not cover all area of the Czech Republic. In fact, the only available map of historical distribution of coppices comes from 1941 (Svoboda \& Weingartel 1941).

Szabó et al. (2015) published their predictive model of potential Late Middle Ages coppice distribution in Moravia based on studies of archival data. For the period between their map (only for the Moravian part of the (zech Republic) and Svoboda's map from 1941, we have no comprehensive information about coppice distribution from the territory of the Czech Republic. Our map of coppice distribution in 1845 is therefore very valuable and extends our knowledge 100 years deeper into the past.
To fill the gap in our knowledge in historical distribution of coppice woodlands before 1845 we constructed the map of natural conditions for the establishment of coppice woodlands based on the developed NC index. Because ancient forests are defined as forest sites continuously wooded since at least 200 years, we developed another way to predict where ancient coppice woodlands are likely to be found among the current forest area. The resulting map constructed using the COP index clearly shows regions with a higher inferred probability of occurrence of ancient coppice woodlands. It is these areas where the inventory should be of the highest priority.

Human influence through forest management is likely to have contributed to the long-term presence of oak in European woodlands (Altman et al. 2013), especially in ancient coppice woodlands. Sustainable management of coppice woodlands resources could be achieved by both considering the traditional management concepts and introducing new ecologically, economically and socially sound management practices (Stajic et al. 2009), as well as by a close cooperation of various state authorities and non-governmental organizations at all levels (local, regional and national).

\section{Conclusions}

The Czech Republic is among the countries in which only very small proportions of woodlands are coppiced. In fact, more than $1000 \mathrm{~km}^{2}$ coppice woods were converted into high forest and stored coppices after World War II. These stored coppices could be the last remainders of ancient coppice woods. The area and distribution of stored coppices is not known in the Czech Republic, because they are often recorded as high forests in forest management plans. Therefore, an inventory of ancient coppice woods is necessary.

The map of predicted occurrence of ancient coppice woodlands based on the COP index could serve as a baseline to support planning of their effective inventory and mapping in the field. The map can help prioritize areas to inventory based on their high probabilities of containing ancient coppice woodlands.

\section{Acknowledgements}

This work has been financed by the Ministry of Culture of the Czech Republic through the project "Ancient coppice woodlands and their significance and sustainability in the cultural landscape" (DF13P01OVV015). The authors would like to express their gratitude to Jonathan Rosenthal for his thorough English revision of the original manuscript.

\section{References}

Altman J, Hédl R, Szabo P, Mazrek P, Riedl V, Müllerová J, Kopecky M, Doleal J (2013). Treerings mirror management legacy: dramatic response of standard oaks to past coppicing in Central Europe. PLoS ONE 8: e55770. - doi: 10.1371/journal.pone.0055770

Anonymous (2012). Standing advise for ancient woodlands. Version 3. Natural England. Web site. [online] URL: http://www.naturalenglan d.org.uk

Benes J, Cizek O, Dovala J, Konvicka M (2006). Intensive game keeping, coppicing and butterflies: the story of Milovicky Wood, Czech Republic. Forest Ecology and Management 237: 353-365. - doi: 10.1016/j.foreco.2006.09.058 Bičík I, Jeleček L, Kabrda J, Kupková L, Lipsky Z, Mareš P, Sefrna L, Stych P, Winklerová J (2010). Vývoj využití ploch v Cesku [Landuse development in the Czech Republic]. Ceská geografická společnost, Edice Geographica, Praha, Czech Republic, pp. 250.

Bond WJ, Midgley JJ (2001). Ecology of sprouting in woody plants: the persistence niche. Trends in Ecology and Evolution 16 (1): 45-51. doi: 10.1016/S0169-5347(00)02033-4

Bradshaw RHW, Jones CS, Edwards SJ, Hannon GE (2015). Forest continuity and conservation value in Western Europe. The Holocene 25 (1): 194-202. - doi: 10.1177/0959683614556378 Brown AHF, Oosterhuis L (1981). The role of buried seed in coppice woods. Biological Conservation 21 (1): 19-38. - doi: 10.1016/0006-3207 (81)90066-5

Buček A, Habrová H, Madra P, Král K, Modr M, Lacina J, Pavlis J (2015). Application of the Czech methodology of Biogeographical landscape differentiation in geobiocoenological concept - examples from Cuba, Tasmania and Yemen. Journal of Landscape Ecology 8 (3): 5167. - doi: 10.1515/jlecol-2015-0014

Chytry M, Kučera T, Kočí M, Grulich V, Lustyk P (2010). Katalog biotopu Ceské republiky [Habitat types cataloque of the Czech Republic]. Agentura ochrany prírody a krajiny $C R$, Praha, Czech Republic, pp. 445.

Decocq G, Aubert M, Dupont F, Alard D, Saguez R, Wattez-Franger A, Foucault BD, DelelisDusollier A, Bardat J (2004). Plant diversity in a managed temperate deciduous forest: understorey response to two silvicultural systems. Journal of Applied Ecology 41: 1065-1079. - doi: 10.1111/j.0021-8901.2004.00960.x

Ellenberg H (1986). Vegetation ecology of Central Europe. Cambridge Universtity Press, Cambridge, UK, pp. 753.

Glaves P, Rotherham ID, Wright B, Handley $\mathrm{CH}$, Birbeck J (2009). Field surveys for ancient woodlands: issues and approaches. A report to the woodland trust. Hallam Environmental Consultants Ltd., Biodiversity and Landscape History Research Institute and Geography, Tourism and Environment Change Research Unit, Sheffield Hallam University, UK, pp. 34. [online] URL: http://nrl.northumbria.ac.uk/1822/ Goldberg E, Kirby K, Hall J, Latham J (2007). The ancient woodland concept as a practical conservation tool in Great Britain. Journal for Nature Conservation 15: 109-119. - doi: 10.1016/ j.jnc.2007.04.001

Hédl R, Kopecky M, Komárek J (2010). Half a century of succession in a temperate oakwood: from species-rich community to mesic forest. Diversity and Distributions 16: 267-276. - doi: 10.1111/j.1472-4642.2010.00637.x 
Kadavy J, Kneifl M, Servus M, Knott R, Hurt V, Flora $M$ (2011). Nízky s strední les jako plnohodnotná alternativa hospodarení malých a stredních vlastníku lesa - obecná východiska. [Coppice and coppice with standards forests - adequate forest management alternative for small and middle forest owners - general starting points]. Lesnická práce, Kostelec nad Cernými lesy, Czech Republic, pp. 296.

Kitching RL (1971). An ecological study of waterfilled tree-holes and their position in the woodland ecosystem. Journal of Animal Ecology 40: 281-302. - doi: 10.2307/3247

Kopecky M, Hédl R, Szabó P (2013). Non-random extinctions dominate plant community changes in abandoned coppices. Journal of Applied Ecology 50: 79-87. - doi: 10.1111/13652664.12010

Lacina J (2016). Coppice woods and pollard trees in the visual arts. Journal of Landscape Ecology 9 (2): 97-108. - doi: 10.1515/jlecol-2016-0010 Machar I (2009). Coppice-with-standards in floodplain forests - new subject for nature protection. Journal of Forest Science 55: 306-311.

Mairota P, Buckley P, Suchomel C, Heinsoo K, Verheyen K, Hédl R, Terzuolo PG, Sindaco R, Carpanelli A (2016). Integrating conservation objectives into forest management: coppice management and forest habitats in Natura 2000 sites. iForest - Biogeosciences and Forestry 9: 560-568. - doi: 10.3832/ifor1867-009

Matula R, Svátek M, Kurová J, Uradníček L, Kadav J, Kneifl M (2012). The sprouting ability of the main tree species in Central European coppices: implications for coppice restoration. European Journal of Forest Research 131: 15011511. - doi: 10.1007/s10342-012-0618-5

Mitchell PL (1989). Repollarding large neglected pollards: a review of current practice and results. Arboricultural Journal 13 (2): 125-142. - doi: 10.1080/03071375.1989.9756411

Mölder A (2016). Small forest parcels, management diversity and valuable coppice habitats: an $18^{\text {th }}$ century political compromise in the Osnabrück region (NW Germany) and its long-lasting legacy. iForest - Biogeosciences and Forestry 9: 518-528. - doi: 10.3832/ifor1834-009

Morhart CD, Douglas CC, Dupraz CH, Graves AR, Nahm M, Paris P, Sauter UH, Sheppard J, Spiecker H (2014). Alley coppice - a new system with ancient roots. Annals of Forest Science 71: 527-542. - doi: 10.1007/s13595-014-0373-5 Müllerová J, Hédl R, Szabo P (2015). Coppice abandonment and its implications for species diversity in forest vegetation. Forest Ecology and Management 343: 88-100. - doi: 10.1016/j. foreco.2015.02.003

Müllerová J, Szabo P, Hédl R (2014). The rise and fall of traditional forest management in southern Moravia: a history of the past 700 years. Forest Ecology and Management 331: 104-115. doi: 10.1016/j.foreco.2014.07.032

Peterken GF (1996). Natural woodland: ecology and conservation in northern temperate regions. Cambridge University Press, Cambridge, UK, pp. 522. [online] URL: http://books.google.com/books?id=p3y43NnvXPYC

Pigott CD (1989). Factors controlling the distribution of Tilia cordata Mill at the northern limits of its geographical range. IV. Estimated age of the trees. New Phytologist 112: 117-121. - doi: 10.1111/j.1469-8137.1989.tboo316.x

Rackham O (1986). The history of the countryside: the full fascinating story of Britain's landscape. JM Dent and Sons, London, UK, pp. 445. Rackham O (2003). Ancient woodland, its history, vegetation and uses in England. Castlepoint Press Colvend, Dalbeattie, Kirkcudbrightshire, UK, pp. 584.

Rackham O (2006). Woodlands. Collins, London, UK, pp. 608.

Rotherham ID, Ardron PA (2006). The archaeology of woodland landscapes: issues for managers based on the case-study of Sheffield, England and four thousand years of human impact. Arboricultural Journal 29 (4): 229-243. doi: 10.1080/03071375.2006.9747465

Spencer JW, Kirby KJ (1992). An inventory of ancient woodlands for England and Wales. Biological Conservation 62 (2): 77-93. - doi: 10.1016/ 0006-3207(92)90929-H

Stajic B, Zlatanov T, Velichkov I, Dubravac T, Trajkov $P$ (2009). Past and recent coppice forest management in some regions of South Eastern Europe. Silva Balcanica 10: 9-19.

Svoboda P (1947). Zastoupení drevin v lesích Ceskoslovenské republiky, díl I [Tree species proportion in forests of the Czech Republic, part I]. Svaz výzkumných ústavu zemedelských a lesnických, Praha, Czech Republic, map 1: 300 000.

Svoboda P, Weingartel V (1941). Mapa lesu podle drevin v bývalém protektoráte Cechy a Morava [Map of forests by tree species in former protectorate Bohemia and Moravia]. Výzkumný ústav lesnické politiky a spravovedy, Praha, Czech Republic, map 1: 300000.

Szabó P (2009). Open woodland in Europe in the Mesolithic and in the Middle Ages: can there be a connection? Forest Ecology and Management 257: 2327-2330. - doi: 10.1016/j.foreco.2009.03. 035
Szabó P (2010a). Ancient woodland boundaries in Europe. Journal of Historical Geography 36: 205-214. - doi: 10.1016/j.jhg.2009.10.005

Szabó P (2010b). Driving forces of stability and change in woodland structure: a case-study from the Czech lowlands. Forest Ecology and Management 259: 650-656. - doi: 10.1016/j.for eco.2009.11.026

Szabó P, Hédl R (2013). Socio-economic demands, ecological conditions and the power of tradition: past woodland management decisions in a Central European landscape. Landscape Research 38: 243-261. - doi: 10.1080/014 26397.2012.677022

Szabó P, Müllerová J, Suchánková S, Kotačka M (2015). Intensive woodland management in the Middle Ages: spatial modelling based on archival data. Journal of Historical Geography 48: 1-10. - doi: 10.1016/j.jhg.2015.01.005

TBFRA (2000). Temperate and boreal forest resource assessment - Forest resources of Europe, CIS, North America, Australia, Japan and New Zealand. UN-ECE/FAO, Contribution to the Global Forest Resources Assessment 2000, Geneva Timber and Forest Study Papers no. 17, Geneva, Switzerland, pp. 445.

Van Calster H, Chevalier R, Van Wyngene B, Archaux F, Verheyen K, Hermy M (2008). Longterm seed bank dynamics in a temperate forest under conversion from coppice-with-standards to high forest management. Applied Vegetation Science 11: 251-260 . - doi: 10.3170/2008-718405

Vandekerkhove K, Baeté H, Van Der Aa B, De Keersmaeker L, Thomaes A, Leyman A, Verheyen K (2016). 500 years of coppice-with-standards management in Meerdaal Forest (Central Belgium). iForest - Biogeosciences and Forestry 9: 509-517. - doi: 10.3832/ifor1782-008

Vlčková V, Buček A, Machar I, Dank T, Pechanec V, Brus J, Kilianová H (2015). The application of geobiocoenological landscape typology in the modelling of climate change implications. Journal of Landscape Ecology 8 (2): 69-81. - doi: 10.1515/jlecol-2015-0010

Vrška T, Janík D, Pálková M, Adam D, Trochta J (2017). Below- and above-ground biomass, structure and patterns in ancient lowland coppices. iForest - Biogeosciences and Forestry 10: 23-31. - doi: 10.3832/ifor1839-009

Winter S, Möller G (2008). Microhabitats in lowland beech forests as monitoring tool for nature conservation. Forest Ecology and Management 255: 1251-1261. - doi: 10.1016/j.foreco. 2007.10.029 